\title{
Can we trust the data? Methodological experiences with forest product valuation in lowland Bolivia
}

\author{
Patricia del Carmen Uberhuaga and Carsten Smith Olsen \\ Danish Centre for Forest, Landscape and Planning, Faculty of Life Sciences, \\ University of Copenhagen, Rolighedsvej 23, 1958 Frederiksberg C, \\ Denmark
}

\begin{abstract}
Forest products are important to rural households across virtually all forest types in developing countries. There are, however, only few comprehensive and systematic efforts at valuing these products and determining their absolute and relative economic importance to rural households. Having used the novel income survey approach developed by the global Poverty and Environment Network (PEN), this paper presents methodological experiences with forest product valuation in lowland Bolivia. Household $(n=118)$ data was collected in six communities in the Tropics of Cochabamba from February 2006 to January 2007. Households used a large number of products, including 151 forest and non-forest environmental products. Valuing all these products was time consuming but possible using the households' own-reported values. Even for non-traded products useful values can be estimated. Generally, using household ownreported estimates result in aggregate unit values with satisfactory properties.
\end{abstract}

Keywords: Economic valuation, methods, Latin America

\section{Introduction}

Around $75 \%$ of the world's poorest people, the one billion persons living on less than USD 1 per day, live in rural areas (Scherr et al. 2004). There is evidence that forest products are harvested in significant quantities by these and better-off households across virtually all forest types in developing countries (Scoones et al. 1992, Pérez and Arnold 1996, Neumann and Hirsch 2000, Cunningham 2001). Frameworks have been developed for analysing and understanding different types of forestdependency (Byron and Arnold 1999) and the continuum of forest-people interactions (Wiersum 1997). Research on the role and potential of forests in preventing and reducing poverty is, however, very limited and can be 
considered an emerging field of inquiry. A few recent case studies indicate that the normally "invisible" forest and environmental incomes can make up a substantial part of rural household incomes. Cavendish (2000), in his pathbreaking investigation in rural Zimbabwe, found that more than $20 \%$ of rural household income was derived from forest and environmental resources, with this share almost doubling for the poorest households. A similar level of forest-dependence and variation in dependence across wealth groups was found by Campbell et al. (2002). In a meta-analysis of 54 case studies, Vedeld et al. (2004) found that on average $22 \%$ of the sampled households' income was derived from forest and environmental resources. They also found that forest income had a strong and significantly equalising effect on local income distribution. However, comparing the existing heterogeneous forest valuation studies is very challenging (Wollenberg and Nawir 1998, Sheil and Wunder 2002, Vedeld et al. 2004). In order to be able to assess the role of forests and other environmental resources in rural livelihoods, the Poverty and Environment Network (PEN) recently developed uniform, best-practice methods for systematic collection of household-level income data (PEN prototype questionnaire 2007, PEN technical guidelines 2007). The present study used these methods. This paper reports methodological findings, using the PEN prototype questionnaire and approach, on forest product valuation in a lowland rainforest site in Eastern Bolivia. The emphasis is on investigating whether own-reported value data is valid and reliable (and thus useful in estimating household incomes); this includes an explicit description of how main products were valuated.

\subsection{Case study area}

Field work was undertaken in the Tropics of Cochabamba, a 39,560 $\mathrm{km}^{2}$ area making up 58\% of the Department of Cochabamba (covering five municipalities) in the Eastern Bolivian lowlands. Annual rainfall is 5573 $\mathrm{mm}$ and annual average temperature is $25^{\circ} \mathrm{C}$. The study area has a population of 146,921 (INE 2001) of which $17 \%$ is found in seven urban areas and the remaining scattered across more than 1000 usually small villages, composed of indigenous groups, such as Yuracare, Yuqui and Mojenos, and in-migrants from the Bolivian highlands. The lowest legally recognised administrative unit is the sindicato, usually compromising only one or a few communities, that are organised in centrales that are again organised in federationes; there are six federationes, 86 centrales and more than 760 sindicatos (UMSS-PROGEO 2005) in the Department of 
Cochabamba. Indigenous communities, in addition, are organised in councils.

Land use is dominated by natural forests $(67 \%)$, followed by agriculture and pasture lands (22\%) with the remaining parts made up of rivers, roads (both important for transport) and settlements (11\%). Agriculture is important in livelihood strategies; soils are generally poor; main subsistence crops are rice, maize and cassava; main commercial crops are coca leaves and fruits (citrus, plantain and cocoa). It is legal for farmers to produce coca leaves on farm plots up to $1600 \mathrm{~m}^{2} /$ household; alternative crops, such as palm heart, pineapple, achiote (Bixa orellana), coffee and camu-camu (Myrciaria dubia), are promoted by development agencies in the study area as is formal forest management (UMSS-PROGEO 2005). Following the introduction of the 1996 forest law in Bolivia, there has been a shift from traditional subsistence use to commercial use of forests in the study area. In 2005, there were around 64 villages with formally approved forest management plans (Proyecto Jatun Sach'a 2005); commercial timber harvesting extracts around $3 \mathrm{~m}^{3} /$ harvest/ha (Malky 2005); and an estimated 150,000 ha is under formal management (UMSS-PROGEO 2005). Due to demand for agricultural and pasture lands, deforestation in the Department of Cochabamba runs at approximately 10-15,000 ha/yr (Proyecto Agroforestal C-23). In general, the rural population in the study area is poor, with $88 \%$ living below the national poverty line and a human development index of 0.56 (UDAPE 2008); agricultural productivity is low and forest dependence high, i.e. with a significant proportion of households using forests to support their current consumption, e.g. through harvest and use of medicinal plants.

To study variation in forest dependence across indigenous groups and in-migrants, three colonist (Asaí, Aliso Colorado, and Ambaibo; all community names used are fictive to provide anonymity to participating communities) and three indigenous (Bejuco, Blanquillo and Bibosi) communities were included. An overview of the selected communities is presented in Table 1. Community selection criteria were: some degree of forest dependency, low coca production (based on previous field work experience from the area, we judged that high (i.e. illegal) coca production would result in invalid household asset and income data as this is a very sensitive issue), accessibility (that is was likely that communities would grant us permission to conduct research), and proximity (for budgetary reasons communities could not be located too far apart). All six communities are involved in formal forest management and are members of the local forest union (organising communities involved in formal forest 
management). All six communities have forests that are similar in composition and structure: closed canopy natural high forest characterised by timber species such as mapajo (Ceiba petambra), verdolago (Terminalia sp.), almendrillo (Dipterex odorata), trompillo (Guarea sp.), ambaibo (Cecropia membranacea), ochoó (Hura crepitans), charque (Eschweilera coriaceae), coquino (Pouteria sp.), jorori (Swartzia jorori) and negrillo (Nectandra sp.).

Table 1 Overview of six studied communities in the Tropics of Cochabamba, lowland Bolivia, 2006-07 (based on data from the household survey and the forest management plans)

\begin{tabular}{|c|c|c|c|c|c|c|}
\hline & Asaí & $\begin{array}{c}\text { Aliso } \\
\text { Colorado } \\
\end{array}$ & Ambaibo & Bejuco & Blanquillo & Bibosi \\
\hline $\begin{array}{l}\text { Yr of } \\
\text { establish. / } \\
\text { legal land } \\
\text { title }\end{array}$ & 1984 / 1999 & 1982 / 1999 & $1996 / 2001$ & $\begin{array}{ll}1970 \mathrm{~s} & / \\
2003 & \end{array}$ & $1982 / 2000$ & $\begin{array}{l}\text { Few hh in } \\
1970 \text {, more } \\
\text { in } 2003 / \\
2006\end{array}$ \\
\hline Area $(h a)^{1}$ & 1294 & 3346 & 6109 & 428 & 487 & 5159 \\
\hline No. of hh & 40 & 119 & 32 & 26 & 24 & 81 \\
\hline Av. hh size & 5.4 & 4.8 & 5.6 & 4.7 & 7.5 & 5.8 \\
\hline $\begin{array}{l}\text { No. of } \\
\text { sampled hh }\end{array}$ & 20 & 37 & 8 & 12 & 12 & 30 \\
\hline $\begin{array}{l}\text { Distance to } \\
\text { market } \\
(\mathbf{k m})\end{array}$ & 35 & 38 & 28 & 20 & 31 & 38 \\
\hline Accessibility & $\begin{array}{l}\text { Road, taxi } \\
\text { service }\end{array}$ & $\begin{array}{l}\text { Road, taxi } \\
\text { service }\end{array}$ & $\begin{array}{l}\text { Road being } \\
\text { constructed, } \\
\text { taxi service } \\
\text { and foot }\end{array}$ & $\begin{array}{l}\text { Road, taxi } \\
\text { service }\end{array}$ & $\begin{array}{l}\text { Road, taxi } \\
\text { service, river }\end{array}$ & $\begin{array}{l}\text { No road, } \\
\text { foot and } \\
\text { cycle path, } \\
\text { river }\end{array}$ \\
\hline $\begin{array}{l}\text { Main } \\
\text { livelihood } \\
\text { activities }\end{array}$ & $\begin{array}{l}\text { Agriculture, } \\
\text { timber, } \\
\text { hunting, } \\
\text { fishing }\end{array}$ & $\begin{array}{l}\text { Agriculture, } \\
\text { timber, } \\
\text { labour in } \\
\text { forest } \\
\text { plantations }\end{array}$ & $\begin{array}{l}\text { Own } \\
\text { business, } \\
\text { agriculture, } \\
\text { some } \\
\text { fishing }\end{array}$ & $\begin{array}{l}\text { Hunting, } \\
\text { fishing, } \\
\text { agriculture, } \\
\text { small scale } \\
\text { livestock }\end{array}$ & $\begin{array}{l}\text { Timber, } \\
\text { agriculture, } \\
\text { hunting }\end{array}$ & $\begin{array}{l}\text { Hunting, } \\
\text { fishing, } \\
\text { agriculture, } \\
\text { some } \\
\text { timber }\end{array}$ \\
\hline $\begin{array}{l}\text { Forest mgt. } \\
\text { plan (ha / yr } \\
\text { approved) }\end{array}$ & $\begin{array}{l}181 / \text { Oct } \\
2004\end{array}$ & $\begin{array}{l}195 \text { / Nov } \\
2004\end{array}$ & $\begin{array}{l}201 \text { / May } \\
2003 \text { (1400 } \\
\text { in prep.) }\end{array}$ & $\begin{array}{l}123 / \text { Apr } \\
2004\end{array}$ & $\begin{array}{l}156 / \text { Aug } \\
1998\end{array}$ & $\begin{array}{l}2000 \text { / in } \\
\text { prep. }\end{array}$ \\
\hline $\begin{array}{l}\text { Per aeu } \\
\text { daily } \\
\text { income } \\
\text { (USD) }^{2}\end{array}$ & 2.45 & 2.27 & 1.47 & 1.40 & 1.29 & 1.16 \\
\hline Notes $^{3}$ & In-migrants & In-migrants & In-migrants & Yuracare & $\begin{array}{l}\text { Mojenos, } \\
\text { share } \\
\text { infrastructure } \\
\text { with colonist } \\
\text { community }\end{array}$ & $\begin{array}{l}\text { Yuracare, } \\
\text { also } \\
\text { resides in a } \\
\text { peri-urban } \\
\text { area } \\
\end{array}$ \\
\hline
\end{tabular}


${ }^{3}$ In-migrants have both private land and communal lands; indigenous groups have communal lands only.

All communities were established fairly recently; all are dependent on agriculture and, for five communities, some degree of hunting and/or fishing. Distances to markets are similar as is accessibility (except for Bibosi that is more isolated). Development of forest management plans were undertaken with the assistance of donor agencies.

\section{Methods}

This section briefly explains how product values were collected. Data collection and handling followed the procedures specified in the PEN prototype questionnaire (2007) and the PEN technical guidelines (2007): first, qualitative rural appraisal at village level was used to generate contextual information about the study area and its people; this information was also used to adopt the prototype questionnaire to the local context. The structured questionnaires were then tested, followed by random selection of households, and application of questionnaires. Appraisal field work started in February 2006 and the last quarterly survey was conducted in January 2007. See Lund et al. (in press) for a discussion of the experiences of using the PEN approach across a range of different sites and conditions.

Before field work could start access to interview households in the six communities had to be negotiated with the association of municipalities as well as the sindicatos and the indigenous councils. Negotiations took three months and resulted in formal written agreements with each community, including agreement on returning preliminary findings to each community in detailed Carpetas Comunales (Uberhuaga in press); these serve to share results as well as providing input to any future development and research projects in the communities.

Data collection was undertaken by a small team of research assistants rather than enumerators; the assistants were social science bachelors (economics or sociology) with some research experience and a lot of research interest. The team was trained in the PEN approach to research and data collection. They worked in sub-teams of two people: one asking the questions and the other taking notes and controlling the development of the interview. The questionnaires were pre-tested in a community in the Tropics of Cochabamba by the research team; the experiences gained were used to fine tune approaches to asking sensitive information and to add extra data collection techniques to the rapid appraisals at community-level. Each evening in the field ended with a team meeting where the day's collected 
data was checked and discussed; inconsistencies and errors were then clarified directly with relevant households the following day.

\subsection{Rapid appraisal}

Contextual information on community history and characteristics were collected using rapid appraisal techniques including communal maps, seasonal activity calendars, resource use flow maps, chronological community history and individual life histories. Communal meetings took three to five hours, mainly in the evening (households are very busy during the day). As the interview team spent between 10 and 15 weeks in each community, it also made participatory observations of households' main livelihood activities (e.g. work in agricultural fields, fishing, wood carving). Direct observations, e.g. of household assets and activities, also formed an important part of the research team members' everyday work; this was used to check the structured survey responses while the interview was going on and probe as required, e.g. to understand in detail the how, when and where of wild fruit collection. Lastly, the research team also recorded long informal conversations with household members.

\subsection{Household-level structured surveys}

Empirical data collection covered the one year period from January 2006 to January 2007. Detailed household-level questionnaires (see PEN prototype questionnaire (2007) and PEN technical guidelines (2007) for further details) were applied at the beginning of the period (focusing mainly on demographics and assets), at the end of the period (focusing mainly on crises in and perceptions of the past year), and quarterly surveys in between (focusing mainly on income). A household in the study area is defined as a "group of people (normally family members) living under the same roof, and pooling resources (income and labour) for their livelihood" (PEN technical guidelines 2007). Most households were made up of family members though occasionally there were households based on ethnic kinship ties. The term community refers to a unit of households with common norms and rights (typically found in scattered villages) under the jurisdiction of a community leader or council.

Up-dated and checked community-level census lists were used to randomly select households for interviews; to enable intra- and intercommunity level analyses around 50\% of households in each community was initially randomly selected. The initial number of households $(n=165)$ was substantially reduced over the study period (final $n=118$ ), especially after the first quarterly household-level interview round where an entire 
community ( $n=31$ ) left the study as it found the interviews too time consuming and delving into sensitive issues, e.g. the questions on savings and the detailed recording of income. See Table 1 for an overview of distribution of sampled households across communities. Generally, the quarterly interviews took more than an hour, depending on the interviewerhousehold relationship - much effort and time was invested in building trust and interviewer-household relationships were very good at the time of the third and fourth quarterly surveys.

\subsection{Data analysis}

Building on the PEN technical guidelines (2007), forest products are defined as products whose supplies depend on the existence of the forest. Forest products are usually collected in forests but mobile products may also be collected outside forests, e.g. an agouti shot in an agricultural field is counted as a forest product as it will not be available if the forest is removed. In the present study, fish are considered non-forest environmental products. Products may be raw or processed. Building on FAO's definition, forests are defined as lands of more than 0.5 ha, with a tree canopy cover of more than $10 \%$, where the trees should be able to reach a minimum height of five meters in situ, and which are not primarily under agricultural land use. Thus, for instance, timber trees grown in agroforestry systems are not counted as forest products but as agricultural products. The data collection instruments were designed to allow distinction between product origins. Forest services are not part of this study.

\section{Results}

In general, the studied households use a large number of forest, nonforest environmental, agricultural and livestock products - we recorded the use of 151 forest and non-forest environmental products. In this paper, for the economically most important products for households, the emphasis is on checking basic distributional statistics for product-level unit values derived from own-reported values. In addition, to increase transparency regarding the valuation techniques, notes are provided on the valuation of economically important forest and non-forest environmental products.

\subsection{Conversion of local volume units to SI units}

Of the 151 forest and non-forest environmental products, used for both subsistence and commercial purposes, 40 products were reported in more than one unit. And more than $50 \%$ of all records were made in local units, e.g. carga (100 pounds) for coca leaves or arroba $(11.5 \mathrm{~kg})$ for citrus fruits. 
Conversions to SI units were done based on standard tables of weights and units (Jaimes et al. 2001, Mancilla 2003, Rowlet 2005).

\subsection{Checking own-reported values}

During data collection households were asked to estimate the total quantity and value of forest and other products used in a specified period (either one or three months) prior to the quarterly interview; this was then used to value the forest, non-forest, agricultural and livestock products. Cavendish (2002) demonstrated, in Zimbabwe, that such own-reported values for forest and non-forest environmental products can be elicited in the same way as values are elicited for other 'normal' economic goods; the household estimates result in aggregate unit values with satisfactory properties. In consequence, estimated values can be used to value resource use in households (in the same season in the same location) that are not able to supply value estimates (or, alternatively, to create a common price for a product in a particular location in a particular period). Whether this approach also yields valid and reliable results when applied in lowland Bolivia is investigated in this section.

Whenever possible own-reported values are based on farm-gate prices; if these are not available, or markets are very thin, barter values (value derived from exchange of product with market commodity), substitute values (value derived from local market price of close substitute), willingness to pay (WTP, group of interviewees agreeing on value of nontraded product) or distant market prices (price on distant market minus transportation costs to market) were estimated. Out of the 151 forest and non-forest environmental products, farm-gate could be recorded for 59 products $(39 \%)$, and barter/substitute/WTP values for 63 products $(42 \%)$. The remaining 29 products (19\%) were all of marginal importance to local households and were not valued; 25 products $(17 \%)$ were mentioned just once across all seasons and households and four products (3\%) were mentioned a few times by a few households. An overview of basic distributional statistics for unit values of the main $(n \geq 5)$ forest, non-forest environmental, agricultural and livestock products are presented in Table 2. The column "Valuation method" specifies how each product was valued. For each product, $n$ is provided for the most disaggregated product (in some cases products were aggregated in the field, e.g. for medicinal plants, and in these cases $n$ refers to the product group where some variation around the mean must be expected).

Table 2 Unit values (Bs) of main $(n \geq 5)$ forest, non-forest environmental, agricultural and livestock products in lowland Bolivia, 2006-07 


\begin{tabular}{|c|c|c|c|c|c|c|c|c|}
\hline Products & $\begin{array}{c}\text { Unit of } \\
\text { measure }\end{array}$ & $n$ & Mean & s.d. & Median & Min & Max & $\begin{array}{c}\begin{array}{c}\text { Valuation } \\
\text { method }\end{array} \\
\end{array}$ \\
\hline \multicolumn{9}{|c|}{ I. Wooden products } \\
\hline Almendrillo & $\mathrm{m}^{3}$ & 5 & 654.3 & 233.2 & 635.6 & 420 & 932.2 & farm-gate \\
\hline Frond & Piece & 11 & 7.1 & 8.1 & 3.0 & 1.0 & 25.0 & substitute \\
\hline Fuelwood & Wheelbarrow & 433 & 8.5 & 4.6 & 10.0 & 2.0 & 50.0 & WTP \\
\hline House & Piece & 10 & 4710.0 & 9164.5 & 1500.0 & 300.0 & 30000.0 & substitute \\
\hline Lianas and vines & Piece & 5 & 2.3 & 2.5 & 0.5 & 0.5 & 5.0 & substitute \\
\hline Poles & Poles & 5 & 16.0 & 5.5 & 20.0 & 10.0 & 20.0 & farm-gate \\
\hline \multirow[t]{2}{*}{ Timber } & $\mathrm{m}^{3}$ & 44 & 377.4 & 243.5 & 423.7 & 100.0 & 848.0 & farm-gate \\
\hline & Piece & 9 & 370.6 & 378.9 & 200 & 80.0 & 1200.0 & farm-gate \\
\hline Tree leaves & Piece & 5 & 0.7 & 0.4 & 1.0 & 0.0 & 1.0 & WTP \\
\hline Woodcraft & Piece & 5 & 20.0 & 12.8 & 20.0 & 5.0 & 40.0 & farm-gate \\
\hline Wooden furniture & Piece & 9 & 95.2 & 122.5 & 50.0 & 2.0 & 400.0 & WTP \\
\hline \multicolumn{9}{|c|}{ II. Non-wooden products } \\
\hline Apple guava & Piece & 5 & 0.4 & 0.4 & 0.2 & 0.05 & 1.0 & substitute \\
\hline \multirow[t]{2}{*}{ Bacuri fruit } & $\mathrm{Kg}$ & 8 & 4.3 & 2.8 & 4.5 & 1.0 & 10.0 & substitute \\
\hline & Piece & 5 & 0.3 & 0.1 & 0.3 & 0.2 & 0.5 & substitute \\
\hline \multirow[t]{2}{*}{ Cacao fruits } & $\mathrm{Kg}$ & 8 & 9.5 & 0.9 & 10.0 & 8.0 & 10.0 & farm-gate \\
\hline & Piece & 5 & 0.9 & 0.4 & 1.0 & 0.5 & 1.5 & farm-gate \\
\hline \multirow[t]{5}{*}{ Cat's claw } & $\mathrm{Kg}$ & 35 & 12.8 & 6.4 & 12.8 & 2.0 & 30.0 & farm-gate \\
\hline & Litres & 24 & 13.7 & 13.6 & 10.0 & 3.0 & 70.0 & farm-gate \\
\hline & $\mathrm{m}$ & 6 & 2.6 & 1.4 & 2.3 & 1.0 & 5.0 & farm-gate \\
\hline & Piece & 14 & 6.4 & 5.8 & 5.0 & 1.0 & 20.0 & farm-gate \\
\hline & Branch & 7 & 1.6 & 1.5 & 1.0 & 1.0 & 5.0 & farm-gate \\
\hline $\begin{array}{l}\text { Chirimoya } \\
\text { silvestre }\end{array}$ & Piece & 9 & 1.1 & 0.5 & 1.0 & 0.5 & 2.0 & farm-gate \\
\hline \multirow[t]{2}{*}{ Malva } & Leaves & 5 & 0.2 & 0.1 & 0.2 & 0.0 & 0.3 & substitute \\
\hline & Stick & 23 & 0.2 & 0.1 & 0.2 & 0.0 & 0.5 & substitute \\
\hline \multirow[t]{5}{*}{ Medicinal plants } & Handful & 8 & 0.8 & 0.1 & 0.8 & 0.8 & 1.0 & substitute \\
\hline & $\mathrm{Kg}$ & 8 & 5.5 & 2.8 & 4.0 & 4.0 & 10.0 & substitute \\
\hline & Leaves & 50 & 0.2 & 0.3 & 0.2 & 0.0 & 2.0 & substitute \\
\hline & Piece & 24 & 0.8 & 1.2 & 0.7 & 0.0 & 6.0 & substitute \\
\hline & Stick & 43 & 0.8 & 0.7 & 0.8 & 0.0 & 3.0 & substitute \\
\hline \multirow[t]{2}{*}{ Pacay } & $\mathrm{Kg}$ & 25 & 2.4 & 1.6 & 1.6 & 0.8 & 5.0 & farm-gate \\
\hline & Piece & 31 & 0.7 & 0.4 & 0.5 & 0.1 & 2.0 & farm-gate \\
\hline \multirow[t]{2}{*}{ Paico } & Leaves & 6 & 0.3 & 0.2 & 0.3 & 0.1 & 0.5 & substitute \\
\hline & Stick & 19 & 0.9 & 1.4 & 0.5 & 0.1 & 6.0 & substitute \\
\hline Patauá fruits & $\mathrm{Kg}$ & 15 & 6.1 & 4.3 & 5.8 & 0.6 & 15.0 & farm-gate \\
\hline Peach palm fruit & $\mathrm{Kg}$ & 30 & 2.3 & 2.3 & 2.0 & 0.4 & 10.0 & farm-gate \\
\hline Thatching grass & Piece & 11 & 2.4 & 2.3 & 1 & 0.3 & 5.0 & substitute \\
\hline \multirow[t]{2}{*}{ Wild fruits } & $\mathrm{Kg}$ & 20 & 3.6 & 3.1 & 2.2 & 0.4 & 13.0 & WTP \\
\hline & Piece & 19 & 0.9 & 0.8 & 0.8 & 0.0 & 3.5 & WTP \\
\hline \multicolumn{9}{|c|}{ III. Game, fish, insect, honey and guan products } \\
\hline Agouti & $\mathrm{Kg}$ & 68 & 11.8 & 2.8 & 12.0 & 5.0 & 18.0 & farm-gate \\
\hline
\end{tabular}




\begin{tabular}{|c|c|c|c|c|c|c|c|c|}
\hline Products & $\begin{array}{c}\text { Unit of } \\
\text { measure }\end{array}$ & $n$ & Mean & s.d. & Median & Min & Max & $\begin{array}{c}\text { Valuation } \\
\text { method }\end{array}$ \\
\hline Armadillo & $\mathrm{Kg}$ & 26 & 7.5 & 2.5 & 6.5 & 5.0 & 12.0 & farm-gate \\
\hline Collared peccary & $\mathrm{Kg}$ & 32 & 7.9 & 2.5 & 8.0 & 5.0 & 15.0 & farm-gate \\
\hline Deer & $\mathrm{Kg}$ & 12 & 8.6 & 2.8 & 8.0 & 5.0 & 15.0 & farm-gate \\
\hline Fish & $\mathrm{Kg}$ & 554 & 9.3 & 3.3 & 10.0 & 2.0 & 25.0 & farm-gate \\
\hline $\begin{array}{l}\text { Game meat - birds } \\
\text { and bats }\end{array}$ & $\mathrm{Kg}$ & 8 & 9.9 & 3.4 & 10.0 & 5.0 & 14.0 & farm-gate \\
\hline $\begin{array}{l}\text { Game meat - } \\
\text { mammals }\end{array}$ & $\mathrm{Kg}$ & 12 & 8.8 & 3.7 & 10.0 & 5.0 & 15.0 & farm-gate \\
\hline Guan & $\mathrm{Kg}$ & 18 & 9.2 & 5.3 & 10.0 & 5.0 & 25.0 & farm-gate \\
\hline Honey (wild) & Litres & 12 & 15.5 & 7.4 & 12.0 & 8.0 & 35.0 & farm-gate \\
\hline Paca & $\mathrm{Kg}$ & 5 & 8.5 & 1.1 & 8.5 & 7.0 & 10.0 & farm-gate \\
\hline Perdiz & $\mathrm{Kg}$ & 5 & 9.8 & 4.0 & 10.0 & 5.0 & 15.0 & farm-gate \\
\hline \multicolumn{9}{|c|}{ IV. Agricultural products } \\
\hline Achiote & $\mathrm{Kg}$ & 25 & 2.9 & 1.1 & 2.8 & 1.2 & 160.0 & $\begin{array}{l}\text { distant } \\
\text { market }\end{array}$ \\
\hline Avocado & Piece & 20 & 0.3 & 0.1 & 0.3 & 0.1 & 0.5 & farm-gate \\
\hline Banana & Bunch & 16 & 6.6 & 2.5 & 5.5 & 4.0 & 11.0 & farm-gate \\
\hline $\begin{array}{l}\text { Plantain (banana - } \\
\text { cooking) }\end{array}$ & Bunch & 318 & 4.7 & 1.3 & 5.0 & 1.5 & 10.0 & farm-gate \\
\hline Plantain (guineo) & Bunch & 14 & 4.9 & 1.6 & 5.0 & 3.0 & 7.0 & farm-gate \\
\hline Beans & $\mathrm{Kg}$ & 7 & 2.2 & 1.0 & 2.0 & 1.3 & 4.0 & farm-gate \\
\hline (fresh) & $\mathrm{Kg}$ & 218 & 0.5 & 0.4 & 0.4 & 0.1 & 4.0 & farm-gate \\
\hline Coca leaves & Pound (lb) & 302 & 10.9 & 2.0 & 10.0 & 4.0 & 20.0 & farm-gate \\
\hline Cucumber & $\mathrm{Kg}$ & 5 & 0.9 & 0.6 & 1.0 & 0.3 & 1.7 & farm-gate \\
\hline Grapefruit & Piece & 6 & 0.3 & 0.3 & 0.2 & 0.1 & 0.8 & farm-gate \\
\hline Palm heart & Piece & 5 & 1.2 & 0.1 & 1.2 & 1.0 & 1.3 & $\begin{array}{l}\text { farm-gate } \\
\text { distant }\end{array}$ \\
\hline Hojas de achiote & $\mathrm{Kg}$ & 5 & 1.0 & 0.0 & 1.0 & 1.0 & 1.0 & market \\
\hline Lemon & Piece & 9 & 0.3 & 0.3 & 0.2 & 0.1 & 1.0 & farm-gate \\
\hline Lime & Piece & 5 & 0.1 & 0.1 & 0.1 & 0.0 & 0.2 & farm-gate \\
\hline Maize & $\mathrm{Kg}$ & 54 & 0.9 & 0.5 & 0.8 & 0.2 & 2.5 & farm-gate \\
\hline Orange & Piece & 76 & 0.1 & 0.0 & 0.1 & 0.0 & 0.3 & farm-gate \\
\hline Pacay (cultivated) & Piece & 6 & 0.5 & 0.3 & 0.5 & 0.2 & 1.0 & farm-gate \\
\hline Pineapple & Piece & 10 & 0.9 & 0.3 & 1.0 & 0.5 & 1.5 & farm-gate \\
\hline Potato & $\mathrm{Kg}$ & 6 & 1.3 & 0.9 & 1.0 & 0.6 & 3.0 & barter \\
\hline Papaya & Piece & 58 & 0.8 & 0.5 & 0.6 & 0.3 & 4.0 & farm-gate \\
\hline Rice & $\mathrm{Kg}$ & 109 & 1.5 & 0.7 & 1.4 & 0.3 & 3.2 & farm-gate \\
\hline Tangerines & Piece & 19 & 0.1 & 0.1 & 0.1 & 0.0 & 0.5 & farm-gate \\
\hline Tomato & $\mathrm{Kg}$ & 8 & 1.6 & 1.0 & 1.5 & 0.5 & 3.0 & farm-gate \\
\hline Walusa & $\mathrm{Kg}$ & 11 & 0.4 & 0.1 & 0.4 & 0.3 & 0.5 & farm-gate \\
\hline \multicolumn{9}{|c|}{ V. Livestock products } \\
\hline Cattle & Piece & 58 & 1415.0 & 461.5 & 1328.5 & 500.0 & 2800.0 & farm-gate \\
\hline Chicken & Piece & 377 & 22.5 & 3.8 & 25.0 & 1.0 & 35.0 & farm-gate \\
\hline Ducks & Piece & 57 & 27.8 & 7.1 & 30.0 & 10.0 & 45.0 & farm-gate \\
\hline
\end{tabular}




\begin{tabular}{|c|c|c|c|c|c|c|c|c|}
\hline Products & $\begin{array}{c}\text { Unit of } \\
\text { measure }\end{array}$ & $n$ & Mean & s.d. & Median & Min & $\operatorname{Max}$ & $\begin{array}{c}\text { Valuation } \\
\text { method }\end{array}$ \\
\hline Eggs & Piece & 268 & 0.5 & 0.1 & 0.5 & 0.2 & 1.0 & farm-gate \\
\hline Goats & Piece & 8 & 58.8 & 23.0 & 60.0 & 30.0 & 80.0 & $\begin{array}{l}\text { farm-gate } \\
\text { distant }\end{array}$ \\
\hline \multirow[t]{2}{*}{ Honey (cultivated) } & $\mathrm{Kg}$ & 13 & 10.7 & 1.3 & 10.5 & 8.5 & 14.0 & \\
\hline & Litres & 9 & 8.9 & 2.3 & 9.0 & 4.0 & 12.0 & market \\
\hline Milk & Litres & 21 & 1.9 & 0.4 & 2.0 & 1.0 & 2.5 & farm-gate \\
\hline Pigs & Piece & 82 & 274.0 & 177.8 & 200.0 & 70.0 & 800.0 & farm-gate \\
\hline Rabbit & Piece & 15 & 14.8 & 6.7 & 12.0 & 5.0 & 30.0 & farm-gate \\
\hline Sheep & Piece & 16 & 77.5 & 37.7 & 80.0 & 30.0 & 170.0 & farm-gate \\
\hline
\end{tabular}

Table 2 shows that the households' own-reported values can be used as a measure of product values - the estimates result in aggregate unit values with satisfactory properties: the standard deviation is much smaller than the mean and the median and modal values are similar and close to the mean. In addition, for products that were reported in more than one unit, the ratio of unit values are similar to the ratio of quantities as we would expect, e.g. one bacuri fruit is valued at $0.3 \pm 0.1 \mathrm{Bs}$ while one $\mathrm{kg}$ is valued at $4.3 \pm 2.8 \mathrm{Bs}$; from household interviews we know that one $\mathrm{kg}$ is made up of around 15 fruits so the $\mathrm{kg}$ price derived from the per fruit price is around $4.5 \mathrm{Bs}$. In Table 2, we would also expect to find that the value of processed products is higher than for the same unprocessed products (e.g. wood vs. processed wood in the form of woodcraft and wooden furniture); however, the local units reported and the lack of accurate quality and volume assessments at product level (e.g. how much wood of what species is used to produce what furniture) does not allow for such comparisons.

There are exceptions to the above patterns, especially for the wooden products, e.g. pieces of timber or wooden furniture. This is due to large differences in quantity (large and small pieces) and quality (use of different species). These differences also explain dispersion in the unit values of key products such as fuelwood; for this and other products some dispersion is also explained by spatial variability, e.g. in fuelwood availability.

In the following, in order to increase transparency regarding the valuation techniques, notes are provided on the valuation of the forest and non-forest environmental products.

Generally important traded forest and non-forest environmental products

Households usually perceive timber as the most valuable forest and environmental product; it is used for construction of houses, furniture and utensils and many species can be sold; farm-gate prices are generally well- 
known especially due to the communities' involvement in formal forest management plans. It was not difficult to value non-traded used species. Reported values were provided in pie tablar $(\mathrm{pt})$ and converted to $\mathrm{m}^{3}(1 \mathrm{pt}=$ $\left.0.00236 \mathrm{~m}^{3}\right)$. Another important forest product is the seasonal peach palm fruit (Bactris gasipaes) harvested mainly from January to April; it is consumed locally in many forms (fruit, powder, alcoholic beverage) and traded; the value is $2.36 \pm 2.31 \mathrm{Bs} / \mathrm{kg}(n=29)$. Another important seasonal fruit product is patauá fruits (Oenocarpus bataua), a source of calcium, proteins, minerals and an olive-like oil, valued at $6.1 \pm 4.3 \mathrm{Bs} / \mathrm{kg}(n=15)$. Wild collected honey is found in small quantities only and used for subsistence consumption while honey from beekeeping (maintenance of honey bee colonies, typically in hives, by households) is sold to an association of producers; both products were easily valuated at 15.5 \pm 7.4 $\mathrm{Bs} / \mathrm{l}(n=12)$ and $8.9 \pm 2.3 \mathrm{Bs} / \mathrm{l}(n=9)$ respectively. Cat's claw (Uncaria guianensis) is the most important medicinal plant; it is consumed in households and sold; nine units of measurements for cat's claw were recorded; it was valued at $12.8 \pm 6.4 \mathrm{Bs} / \mathrm{kg}(n=35)$. The most important fish species are sabalo (Prochilodus nigricans) and pacu (Colossoma brachypomum); again, these are both consumed locally as well as traded and were valued using farm-gate prices; a few households specialise in commercial fishing of these species. We recorded use of another 25 fish species in the study area (all just coded as fish along with sabalo and pacu in the data base); they are usually harvested in small amounts for immediate cooking (breakfast or dinner). These were valued based on comparison with sabalo and pacu; all unit values were lower for these 25 species. The average value for all fish species is $9.3 \pm 3.3 \mathrm{Bs} / \mathrm{kg}(n=554)$. Fruits (and seeds) of cacao (Theobroma cacao) are collected in the forests in the dry season (May to September); seeds are either sold or dried for preparation of traditional chocolate. Not many families work with this product as it is not common; however, prices were well-known $(9.5 \pm 0.9 \mathrm{Bs} / \mathrm{kg}, n=8)$.

\section{Generally important but non-traded forest and non-forest environmental products}

The single most important source of energy, used by all households, is fuelwood - this product is abundant, large forest areas are very close to all communities and households, and not traded. Few households in the study area use substitutes. The most common fuelwood unit was the wheelbarrow (also common was the cocinada: the daily amount required for cooking) which is commonly used for fuelwood transportation from forest-to-house; the average value was estimated at $8.5 \pm 4.6 \mathrm{Bs} /$ wheelbarrow $(n=433)$. 
Value dispersion reflects spatial variability (across communities and households) due to differences in availability (e.g. in three of the communities cut trees were available in abundance due to recent clearance of forest for agricultural fields) and quality (species composition and moisture content). Regarding medicinal plants, we noted the use of 50 species and nine units of measurement; only cat's claw (see above) is traded. The rest are reported to be abundant, in low demand and solely used for self-consumption. Most medicinal plant products are harvested in the forest (leaves $28 \%$, branches $39 \%$, seeds or fruits $28 \%$ and resins/oils $5 \%$ ), but home gardens and fallows are also important supply sources. Deriving substitute prices from locally available allopathic medicine treating similar conditions was not done due to questions of differences in efficacy. Instead we asked households to provide a subjective valuation by (i) comparing to cat's claw - used for species used to treat the same conditions, such as stomach problems and children diarrhoea, as cat's claw; this included the species asai (Euterpe precatoria), raiz amarga (Gentiana asclepiadea) and retoño de guayaba (sprout of apple guava - Psidium guajava); as expected such valuations always resulted in lower values than for cat's claw; (ii) asking how they would barter a specified medicinal plant product amount with four breads (valued at Bs 1) or one egg (valued at Bs 0.5). For the most common medicinal plants, such as paico (Chenopodium ambrosioides), we got a value of $1.0 \pm 1.4 \mathrm{Bs}$ per unit (such as one piece used to prepare an application, e.g. paico tea), while less common species were valued around $0.2 \pm 0.1$ Bs per unit.

Occasionally important, occasionally traded forest and non-forest environmental products

This group of products is usually used for subsistence purposes only; households prefer alternatives but they remain seasonally important and serve safety net functions in times of hardship - when local markets are also established for these products. Prices thus vary among years and seasons. The observed year was a normal year, compared with the last five years, except that all communities were affected by floods leading to some crop losses in the last quarter of 2006.

Valuation of wild fruits (pacay, maracuya, ocoro, carambola, chirimoya silvestre) was done by households for the most common products, including pacay (Inga sp.; $2.4 \pm 1.6 \mathrm{Bs} / \mathrm{kg}, n=22$ ) and chirimoya silvestre (Rollinia edulis; $1.1 \pm 0.5 \mathrm{Bs} /$ piece, $n=7$ ). For these products, with an occasional market, farm-gate prices could be obtained. For other products, values were obtained through discussions where villagers 
identified substitute values or their willingness to pay for a particular product; values, usually per piece of fruit or per $\mathrm{kg}$, were typically identified from comparison with traded fruits or agricultural products with known values. The non-traded wild fruits were valued lower than traded wild fruits, such as patauá fruits mentioned above; e.g. bacuri fruit (Garcinia spp.) was valued at $0.3 \pm 0.1 \mathrm{Bs} /$ piece $(n=5)$ and apple guava (Psidium guajava) at $0.4 \pm 0.4 \mathrm{Bs} /$ piece $(n=5)$. Less common wild fruits were assigned one common value $(3.2 \pm 2.9 \mathrm{Bs} / \mathrm{kg}, n=24)$. Thatching grass is used to make roofs; many different species are used including palm, chuchio and palla leaves. Households found valuation difficult $(2.4 \pm 2.3 \mathrm{Bs} /$ piece, $n=11)$ and future valuation efforts would benefit from distinguishing thatching grass products as quality varies significantly. The same is probably true for lianas and vines $(2.3 \pm 2.5 \mathrm{Bs} /$ piece (usually $2 \mathrm{~m}), n=5$ ) used for binding. Regarding game meat, households found it easy to value meat that was frequently hunted and occasionally traded such as agouti $(11.8 \pm 2.8 \mathrm{Bs} / \mathrm{kg}, n$ $=68)$, collared peccary $(7.9 \pm 2.5 \mathrm{Bs} / \mathrm{kg}, n=32)$ and armadillo $(7.5 \pm 2.5$ $\mathrm{Bs} / \mathrm{kg}, n=26$ ). However, other less frequently hunted and traded species, such as parrots, monkeys and white-lipped peccary, were more difficult to value. These were eventually valued using farm-gate prices, obtained through interviews with hunters in an indigenous neighbouring village, located three $\mathrm{km}$ down the river, who were locally known to regularly provide local markets with game meats. Trade in illegal products, such as skins and live animals, were not observed or recorded.

\section{Discussion and conclusion}

Households in the study area used a huge array of forest, non-forest environmental, agricultural and livestock products that are both traded and consumed locally; valuing all these products is time consuming but possible using the households' own-reported values. Even for non-traded products useful estimates can be collected. The resultant aggregated unit values generally have satisfactory properties. For key products, those that are commonly used by households, the quality of own-reported data can be increased by (i) explicitly specifying product quality differences, e.g. by attempting to distinguish main types of fuelwood - the better defined a product is the less variation in value estimates due to not recorded quality differences, and (ii) collecting information on local volume units at product level; this would allow more thorough cross-check of the ratio of reported unit values to the ratio of quantities.

When using own-reported values in income calculations, it could be argued that it would be most appropriate to use aggregated average product 
prices, rather than the individual household-level recorded values, in order to avoid household-level preferences influencing income estimates. However, this paper indicates that such an approach should not be used as, as also noted by Cavendish (2002), the household-level values are likely to be more accurate: (i) units of measurements are not identical, e.g. a collared peccary or a wheelbarrow of fuelwood may be either small or large, (ii) there are large not recorded product differences, e.g. the wheelbarrow of fuelwood can also vary in species composition and moisture content, and (iii) there is spatial variability in values, e.g. fuelwood may require less labour to collect in some villages.

\section{References}

Banco Central de Bolivia. 2007. Boletín Estadístico No. 335-Septiembre 2007, December 2007. Banco Central de Bolivia - BCB: La Paz, www.bcb.gov.bo/sitio/loader1.php

Byron, R.N. and Arnold, J.E.M. 1999. What futures for the people of tropical forests? World Development 27(5): 789-805.

Campbell, B.M., Jeffrey, S., Kozanayi, W., Luckert, M., Mutamba, M. and Zindi, C. 2002. Household livelihoods in semi-arid regions: options and constraints. CIFOR: Indonesia.

Cavendish, W. 2000. Empirical regularities in the poverty-environment relationships of rural households: evidence from Zimbabwe. World Development 28(11): 1979-2003.

Cavendish, W. 2002. Quantitative methods for estimating the economic value of resource use to rural households. In: Campbell, B.M. and Luckert, M.K. (eds), Uncovering the hidden harvest: valuation methods for woodland and forest resources. Earthscan Publications Ltd, London. pp. 17-66.

Cunningham, A.B. 2001. Applied ethnobotany. Earthscan Publications, London.

INE, 2001. Censo de Polacion y Vivienda. Instituto Nacional de Estadística - INE: La Paz.

Jaimes, H., Pezet, F. and Hernándes, I. 2001. El sistema internacional de unidades (SI). Publicación tecnica CNM-MMM-PT-003. Centro Nacional de Metrología - CENAM: Querétaro, Mexico.

Lund, J. F, Larsen, H.O., Chhetri, B.B.K., Rayamahi, S., Nielsen, Ø.J., Olsen, C.S., Uberhuaga, P., Puri, L. and Córdova, J.P.P. in press. When theory meets reality - how to do forest income surveys in practice. Forest and Landscape Working Paper, Faculty of Life Sciences, University of Copenhagen, Copenhagen. 
Mancilla, R. 2003. Manual para estimar el volumen de madera en troza y aserrada. CONAP-ACOFOP. Guatemala.

http://www.educacionforestal.org/documentos.htm. Accessed 16 June, 2008.

Malky, H. 2005. Sector Forestal en Bolivia. Diagnosticos Sectoriales. Unidad de Analisis y Políticas Sociales y Económicas - UDAPE): La Paz.

Neumann, R.P. and Hirsch, E. 2000. Commercialisation of non-timber forest products: review and analysis of research. CIFOR: Bogor.

PEN questionnaire 2007. PEN Prototype Questionnaire. Version 4 (May 2007). Poverty Environment Nework.

http://web.cifor.cgiar.org/pen/_ref/tools/index.htm, accessed 16 June 2008.

PEN technical guidelines 2007. PEN Technical Guidelines. Version 4 (May 2007). Poverty Environment Nework.

http://web.cifor.cgiar.org/pen/_ref/tools/index.htm, accessed 16 June 2008.

Pérez, M.R. and Arnold, J.E.M. (eds). 1996. Current issues in non-timber forest products research. CIFOR: Bogor.

Proyecto Agroforestal C-23. 2003. Informe del análisis multitemporal de imágenes satélites para la estimación de pérdida de cobertura forestal primaria y evaluación del cambio de uso de suelo en el bosque de uso múltiple del Trópico de Cochabamba. FAO-Proyecto C-23: Cochabamba.

Proyecto Jatun Sach'a. 2005. Proyecto Jatun Sach'a: 10 años construyendo una cultura forestal. FAO-Proyecto Jatun Sach'a I79: Cochabamba.

Rowlet, R. 2005. A dictionary of units of measurement. University of North Carolina at Chapel Hill, http://en.wikipedia.org/wiki/Conversion_of_units, accessed 16 June 2008.

Scherr, S.J., White, A. and Kaimowitz, D. 2002. Strategies to improve rural livelihoods through markets for forest products and services. Forest Trends: Washington DC.

Scoones, I., Melnyk, M. and Pretty, J.N. 1992. The hidden harvest: wild foods and agricultural systems. IIED: London.

Sheil, D. and Wunder, S. 2002. The value of tropical forests to local communities: complications, caveats, and cautions. Conservation Ecology 6(2): art9. 
Uberhuaga, P. in press. Communal Notebooks. Technical Notes 1-6. Escuela Forestal-Universidad Mayor de San Simo - Proyecto FOMABO: Cochabamba.

UDAPE, 2008. Dossier de Estadísticas. Datos Pobreza y Desigualdad. Indicadores Municipales. Unidad de Análisis de Políticas Sociales y Económicas - UDAPE: La Paz (http://www.udape.gov.bo/).

UDAPE, 2006. Pobreza y Desigualdad en Municipios de Bolivia: estimacion del gasto de consumo combinado el censo 2001 y las encuestas de hogares. Segunda edición.UDAPE-INE. La Paz. (htpp://www.udape.gov.bo/)

UDAPE/INE, 2001. Bolivia: Mapa de Pobreza. UDAPE: La Paz. (http://www.udape.gov.bo/mapapobreza2001/id3.htm)

UMSS-PROGEO. 2005. Atlas del Trópico de Cochabamba. Kipus. Cochabamba.

Vedeld, P, Angelsen, A., Sjaastad, E. and Berg, G.K. 2004. Counting on the environment: forest incomes and the rural poor. Environmental economics series 98, The World Bank Environmental Department, the World Bank, Washington D.C.

Wiersum, K.F. 1997. Indigenous Exploitation and management of tropical forest resource: an evolutionary continuum in forest-people interactions. Agriculture, Ecosystems and Environment 63: 1-16.

Wollenberg, E. and Nawir, A.S. 1998. Estimating the incomes of people who depend on forests. In Wollenberg, E. and Ingles, A. (eds) Incomes from the forests, CIFOR, Bogor, pp.157-187. 